\title{
Perception of Teachers in the use of Electronic Platforms to Support Face-to-Face Teaching During the term of The State of Emergency due to Covid-19: Case of the Pedagogical University of Maputo
}

\author{
Manuel Constantino Zunguze ${ }^{12}$ and Malaquias Zildo António Tsambe ${ }^{3}$
}

'Faculty of Economics and Management and 'Faculty of Engineering and Technology Pedagogical University of Maputo (UP-Maputo) - Maputo, Mozambique

${ }^{3}$ Faculty of Natural Science and Mathematics - Pedagogical University of Maputo (UPMaputo) - Maputo, Mozambique

\{manuelczunguze,m.tsambe\} @gmail.com

\begin{abstract}
COVID-19 pandemic forced most of the high education institutions to revert their teaching and learning process from face-to-face teaching system to the process of teaching and learning through the use of electronic platforms. Due to this situation, each high education institution has defined one or a set of electronic platforms to continue to guarantee the effectiveness of teaching classes during this period. It was from the above that this research was developed, which aimed to analyze the perception of teachers at the Pedagogical University of Maputo about accessibility and the use of electronic platforms as a resource to support face-to-face teaching during the term of COVID-19 pandemic. The results showed that most of the teachers interact with the students via WhatsApp and Email through their mobile devices and laptops.
\end{abstract}

Keywords: COVID-19. Electronic platforms. Teaching and learning.

Percepção de Professores na Utilização de Plataformas Electrónicas de Apoio ao Ensino Presencial durante o período do Estado de Emergência devido à Covid-19: Caso da Universidade Pedagógica de Maputo

Resumo. A pandemia do COVID-19 obrigou a maioria das instituições de ensino superior a reverter seu processo de ensino e aprendizagem do ensino presencial para o ensino e aprendizagem mediado por meio do uso de plataformas eletrônicas. Devido a esta situação, cada instituição de ensino superior definiu uma ou um conjunto de plataformas eletrónicas para continuar a garantir a eficácia das aulas neste período. Foi a partir do exposto que se desenvolveu esta pesquisa, que teve como objetivo analisar a percepção dos docentes da Universidade Pedagógica de Maputo sobre a acessibilidade e a utilização de plataformas eletrónicas como recurso de apoio ao ensino presencial durante o período da pandemia do COVID-19. Os resultados mostraram que a maioria dos professores interage com os alunos via WhatsApp e e-mail por meio de seus dispositivos móveis e laptops.

Palavras-chave: COVID-19. Plataformas eletrônicas. Ensino e aprendizagem.

\section{Introduction}

The COVID-19 pandemic influences different processes, systems and, above all, societies lifestyles. Mozambique, like the different countries in the world, had to adopt measures conducive to this new reality. 
The National Education System (SNE) also underwent the challenge of adapting to the new reality, especially with the declaration of the State of Emergency imposed by the spread of COVID-19. It was in this context that the different Education subsystems in Mozambique had to adopt specific measures in order to guarantee the continuity of the teaching and learning process. Higher education institutions have chosen to continue with the teaching and learning processes through different electronic platforms, a methodology provided in the Strategic Plan for Distance Learning (PEED). The PEED (2013) refers to the perspective of implementing Distance Learning in Mozambique, defining distance education as being "the teaching model that is distinguished by the separation between student and teacher, use of technology to mediate learning, two-way communication that allows interaction between students, teachers and tutors and the possibility of face-to-face meetings for tutorials ".

Mozambique currently has about 22 public and 31 private higher education institutions (HEIs). Of these only, two private HEIs practice distance learning in all the courses they provide. The Pedagogical University of Maputo (UP-Maputo) and the Eduardo Mondlane University are characterized by having some experience in distance learning, through their Distance Learning Centers. All the others are characterized by practicing teaching in person. Due to the declaration of a state of emergency, with its precepts defined in Presidential Decree No. 11/2020 of 30 March, all HEIs were obliged to revert their teaching and learning process from the On-site Teaching system to the process of teaching and learning through the use of electronic platforms.

(ZUNGUZE and TSAMBE, 2020) calls for attention to the need for Mozambican HEIs to adapt to the knowledge society in reference to the precepts defined by UNESCO, through the adoption of different forms of teaching and learning, having, naturally, a profound impact at the level of methodologies, practices and paradigmatic, organizational, pedagogical and social approaches of each one. As a result of this situation, each HEI has defined one or a set of electronic platforms to continue to guarantee the effectiveness of the teaching of classes during the term of the Decree. It was from the above that the present research described, aimed to analyze the perception of teachers at UP-Maputo about accessibility and the use of electronic platforms as a resource to support classroom teaching during the term State of Emergency.

\section{Digital Platforms and the Teaching and Learning Process}

In the context of the present study, digital learning platforms are virtual environments created from the resources of Information and Communication Technologies (ICT), which use the Internet as a means of diffusion and communication (DELGADO and HAGUENAUER, 2010). And not in an aspect explored by Samartinho (2010) of distance learning based on b-learning (blended learning) which is composed of an online and a face-to-face part. Thus, digital platforms should be understood as auxiliary to a teaching and learning process transformed into a teaching and learning process completely online (GOMES, 2008); (DELGADO and HAGUENAUER, 2010). This type of teaching finds its support in Internet-based technologies, where learning takes place remotely. In this modality, digital platforms are expected to offer a wide range of resources, which allow the management of academic activities, through the creation of classes, the provision of communication tools between participants and the creation, in real time, of immersive and interactive environments (DELGADO and HAGUENAUER, 2010) and (ZUNGUZE and TSAMBE, 2020).

Regarding the role of the teacher in a teaching modality through the use of digital platforms, Ceccim and Feuerwerker (2004) calls attention to the fact that the prevalence of protagonism is restricted to the figure of the teacher, who in the traditional model, acts by reproducing a teaching model centered on transmission massive content, in which students are seen as recipients of technical-scientific information about a given 
content in a perspective where they are unaware of the active role in the teaching and learning process. Thus, the use of digital platforms in this model of teaching and learning constitutes a challenge resulting from the lack of planning for its use in the Mozambican context, as it arises from the situation of the COVID-19 Pandemic, all forms of measuring its reach, impact and challenges are absent (ZUNGUZE and TSAMBE, 2020).

In the current context, with the declaration of the state of emergency, urges the need for significant changes in the teaching process, where the teacher is challenged to master not only the syllabus of each discipline, but also the platforms to guarantee student learning. Thus, it is up to the teacher to offer the respective distance from the position of sole holder of knowledge and also assume the role of learner (FREIRE, 1996). This context is characterized by the redefinition of the roles and places occupied by the different subjects involved in this process, particularly teachers, students and education managers. It is the student's duty to assume a more active role, resigning the attitude of merely receiving content and autonomously seeking knowledge relevant to the problems and learning objectives (ZUNGUZE and TSAMBE, 2020). This stance implies, on the one hand, greater responsibility on the part of the stakeholders and particularly, greater autonomy in the construction of knowledge by the students (PALÁCIO and STRUCHINER, 2016).

\section{Methodology}

This research was carried out at UP-Maputo. The research had a quanti-qualitative character, where the analysis of accessibility and use of electronic platforms was made as a resource to support face-to-face teaching during the validity of the State of Emergency due to COVID-19.

Methodologically, the present research consisted of gathering information about the objectives of the operationalization of the teaching and learning process due to the COVID-19 pandemic, through the application of a questionnaire to the teachers of UPMaputo in relation to the use of electronic platforms in the support for the teaching and learning process. The questionnaire consisted of 15 questions, 12 of which were multiple choice and 3 were categorized on the Likert scale. The questions categorized on the Likert scale had 12, 7 and 6 items, respectively. The questionnaire can be seen at the link https://forms.gle/pYxW5ie2iMKTeRLg9.

The survey was conducted electronically, using Google Forms. The invitations to reply were sent by WhatsApp during April 2020, a period characterized by the implementation of the Presidential Decree and the validity of the State of Emergency due to COVID-19. The questionnaire was sent to WhatsApp groups in all the faculties of the University, that is, the questionnaire was sent to 429 teachers, which corresponds to the total number of teachers from the Pedagogical University of Maputo and we had 87 questionnaires answered, which corresponds to a rate of responses of $20.28 \%$. This response rate is considered excellent considering that for the size of the population (429 teachers from the UP-Maputo in the academic year 2020) with a 95\% confidence level and a margin of error of $10 \%$, a sample of 79 respondents was sufficient.

\section{Presentations and Discussion of Results}

The first question of the questionnaire was to know in which faculty teaches each teacher participating in the survey. The results are shown below in figure 1 . 


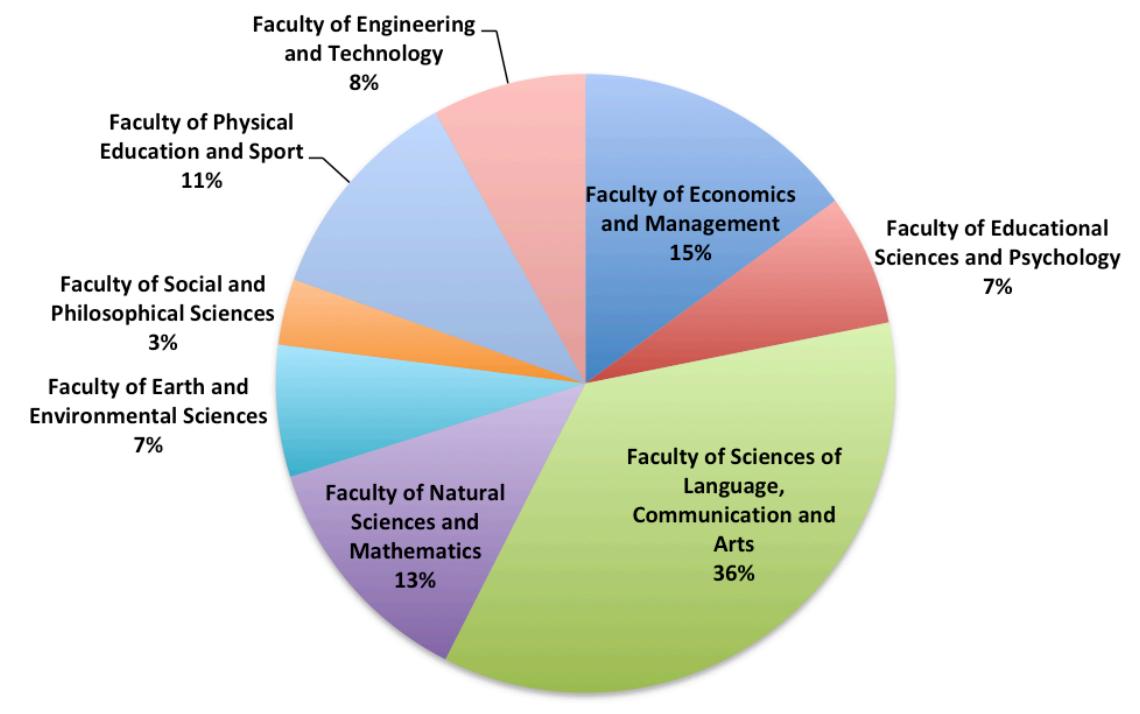

Figure 1. Distribution of teachers by Faculty

As can be seen in figure 1, the study covered all teachers from the different faculties of UP-Maputo. In terms of participation, the Faculty of Sciences of Language, Communication and Arts came first with $38 \%$ of the total participants, followed by the Faculty of Economics and Management with $16 \%$. The faculties with the least number of participants were the Faculty of Physical Education and Sport with $6 \%$ and the Faculty of Social and Philosophical Sciences 4\%.

Of the total number of teachers who answered the questionnaire, $61 \%$ have more than 10 years of experience, $19 \%$ have between 5 and 10 years of experience and the remaining $20 \%$ have less than 5 years of experience.

Teachers were asked if they had ever used an electronic platform to support the teaching and learning process before the Covid-19 pandemic broke out. $86.2 \%$ of the teachers answered yes to that question and $13.8 \%$ answered no. For those who answered yes, we wanted to find out the platforms they used. The results are shown in the following figure.

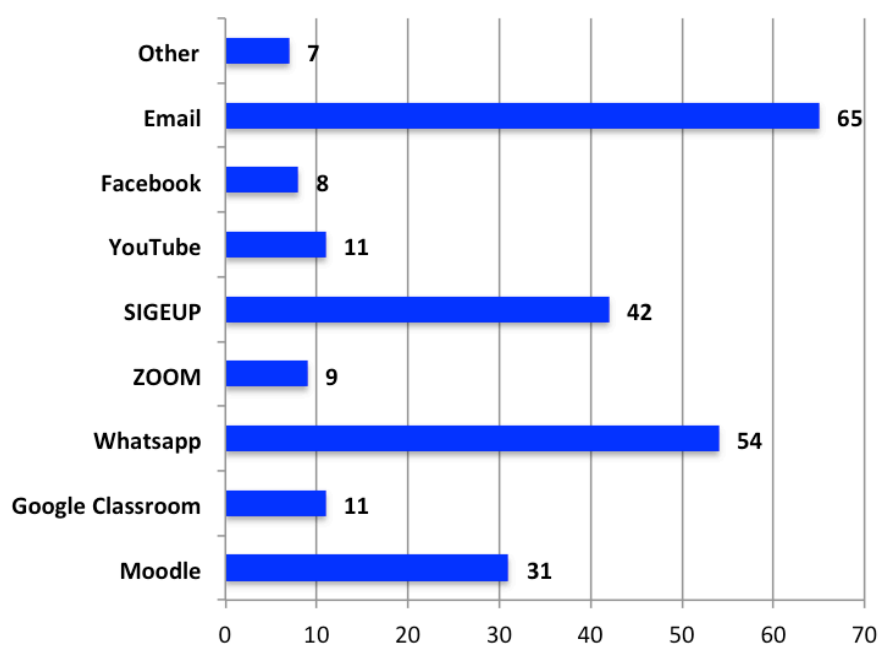

Figure 2. Distribution of teachers by Electronic Platforms used before the COVID-19 pandemic and the declaration of a state of emergency.

The result shows that most of the teachers used Email (74.7\%), WhatsApp (62\%) and SIGEUP (48.2\%). It is important to emphasize that SIGEUP is a Learning Management 
System developed by UP-Maputo. With this question, a much higher percentage of teachers who answered SIGEUP were expected, since this platform is the official platform of the University and all the teachers are registered in it. These answers are supported by the answers to the following question in which it was sought to know if teachers have ever benefited from training in the use of some distance-learning platform. The results showed that $48 \%$ of teachers had some training in the use of distance learning platforms while the 52\% never had any training.

In the next question, we sought to know from the teachers, which Electronic Platforms were using after the outbreak of the Covid-19 pandemic and the declaration of the state of emergency. The results are shown in the figure 3 below.

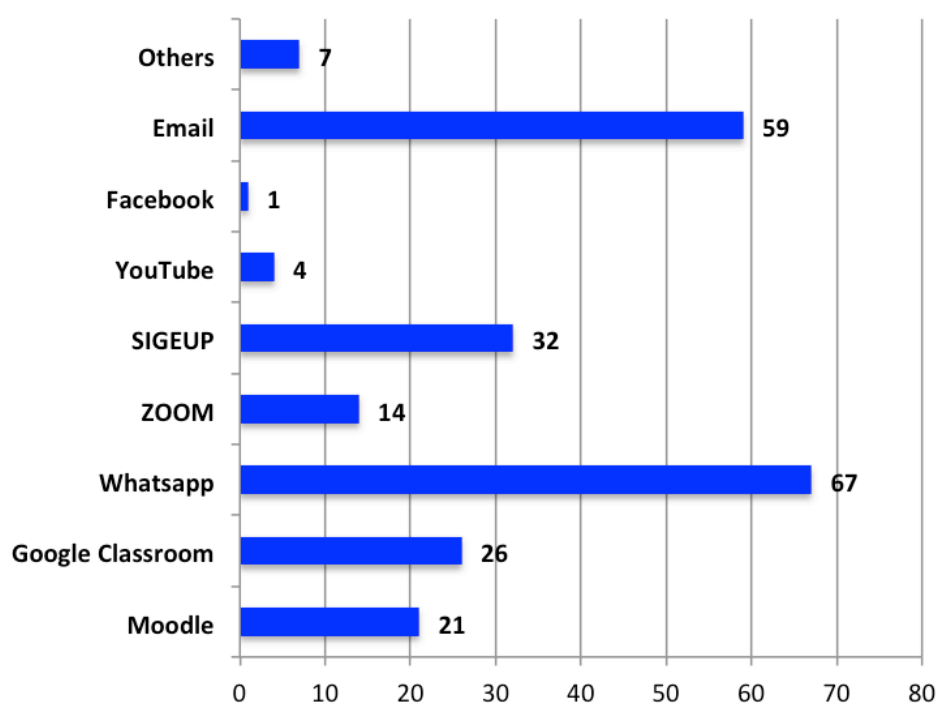

Figure 3. Distribution of teachers by Electronic Platforms used after the COVID-19 pandemic and the declaration of a state of emergency.

The results shown in figure 3 , are similar to the results presented in figure 2 . This result shows that although the University has MOODLE and SIGEUP, the financial condition of teachers and students determined the choice of WhatsApp and Email for online classes (ZUNGUZE and TSAMBE, 2020). As stated by Zunguze and Tsambe (2020) this is justified by the financial condition of the students as most of them only have access to Internet using their cell phones.

These results are reinforced by the answers to the following question in which we wanted to know the devices used by the teachers to conduct their classes. The results are shown in figure 4.

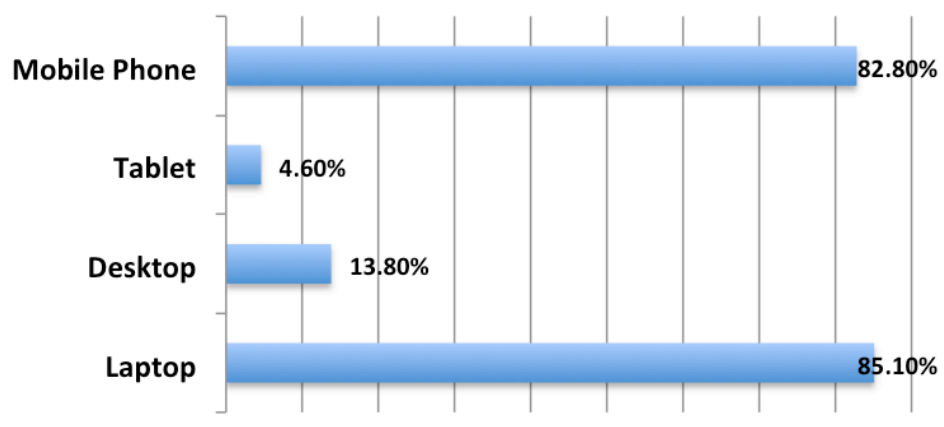

Figure 4. Distribution of teachers by device used to access electronic platforms and conduct classes. 
The results shown in figure 4 shows that, $85.1 \%$ and $82.8 \%$ of the teachers access the electronic platforms from their laptop and mobile phones respectively.

The following question was to know the teaching-learning activities more targeted to students on electronic platforms.

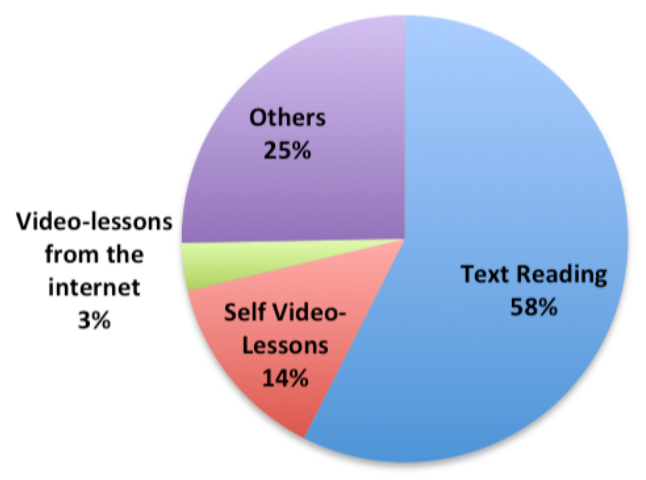

Figure 5. Teaching-learning activities targeted at students by teachers on electronic platforms.

Educational resources directed to students by teachers were text reading with $58 \%$, selfvideo lessons with $14 \%$ and video lessons from the Internet with $3 \%$. The remaining $25 \%$ were a diversification of resources, among them the resolution of questionnaires and interaction via WhatsApp, resolution of practical exercises, debates on topics proposed by the teachers, debate of topics of interest to the class, composition of argumentative texts, elaboration of reading sheets and small research papers. After knowing the activities directed by the teachers to the students, we asked them, how they evaluated the students.

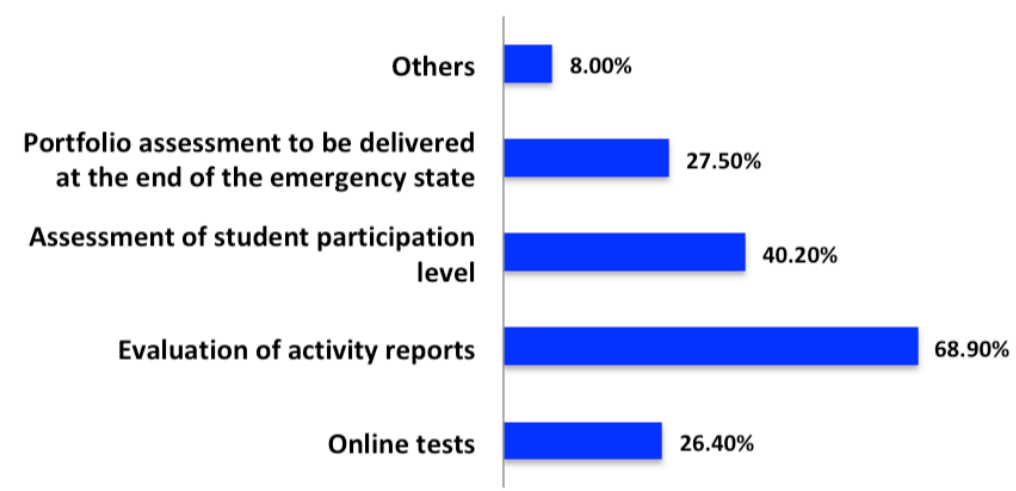

Figure 6. Activities evaluated.

Most teachers $68.9 \%$, evaluated activities report of the students. The other forms of evaluation beside online tests with $26.4 \%$ was assessment of students' participation level and assessment of portfolios to be delivery at the end of the emergency state with $40.2 \%$ and $27.5 \%$ respectively. This shows that even with the change in the teaching format of the classes, the teachers were concerned with evaluating the students as a way of measuring the evolution of the students in relation to the subjects taught.

The other forms of assessment that teachers used, corresponding to $8 \%$, were selfassessment and peer review, research papers, seminars and homework, group work, autobiographical narratives, production of didactic materials and project work.

We tried to find out from the teachers how often they used electronic platforms. The question consisted of 11 items. The results are in the figure 7. 


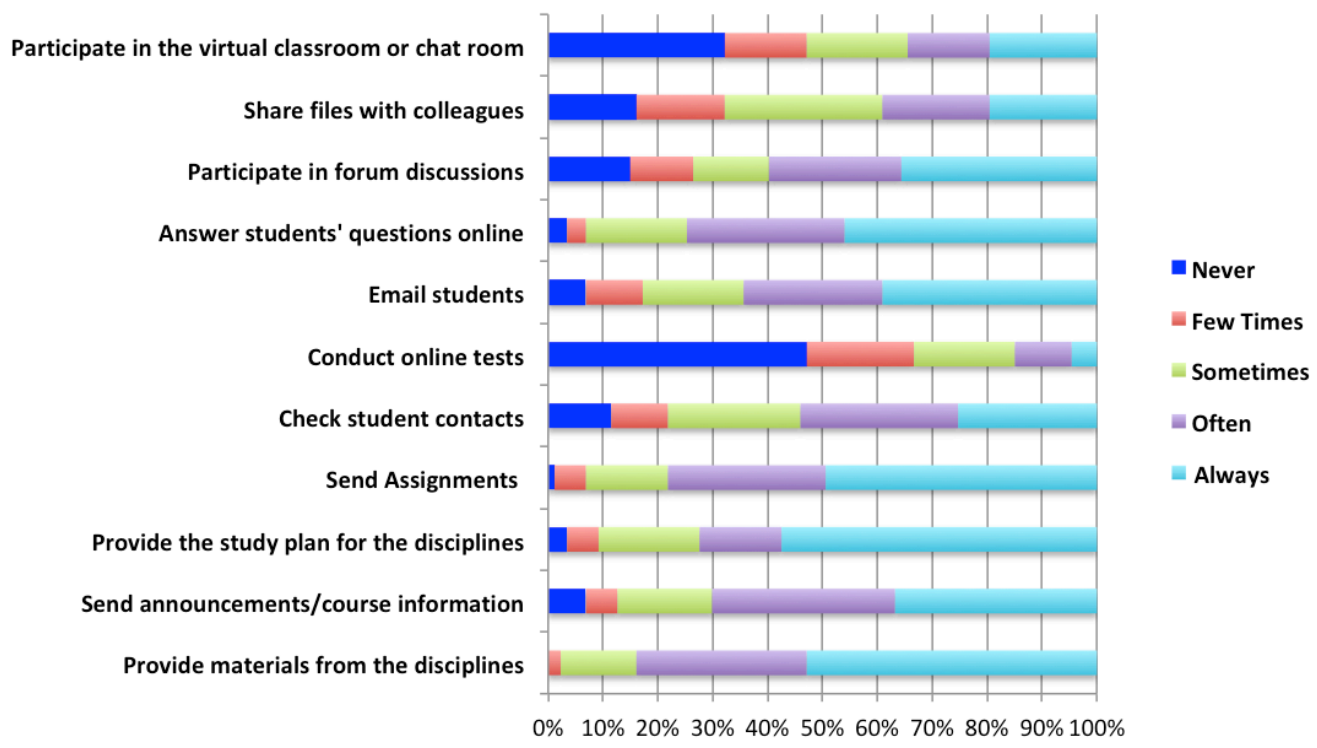

Figure 7. Frequency of usage of electronic platforms.

To analyse the results of the teachers on the use of electronic platforms the method of analysis of the Average Ranking was used. Table 1 shows the data obtained from the teachers' response to each of the five options, based on the Likert scale for eleven items of the question.

Table 1: Average ranking of the items of frequency of use of electronic platforms

\begin{tabular}{|c|c|c|c|c|c|c|}
\hline \multirow[t]{2}{*}{ Item } & \multicolumn{6}{|c|}{$\begin{array}{l}\text { Frequency of responses for each } \\
\text { item }\end{array}$} \\
\hline & 1 & 2 & 4 & 4 & 5 & $\overline{\mathbf{A R}}$ \\
\hline 1. Provide materials from the disciplines & 0 & 2 & 12 & 27 & 46 & 4.344 \\
\hline 2. Send announcements/course information & 6 & 5 & 15 & 29 & 32 & 3.873 \\
\hline 3. Provide the study plan for the disciplines & 3 & 5 & 16 & 13 & 50 & 4.172 \\
\hline 4. Send Assignments & 1 & 5 & 13 & 25 & 43 & 4.195 \\
\hline 5. Check student contacts & 10 & 9 & 21 & 25 & 22 & 3.459 \\
\hline 6. Conduct online tests & 41 & 17 & 16 & 9 & 4 & 2.057 \\
\hline 7. Email students & 6 & 9 & 16 & 22 & 34 & 3.793 \\
\hline 8. Answer students' questions online & 3 & 3 & 16 & 25 & 40 & 4.103 \\
\hline 9. Participate in forum discussions & 13 & 10 & 12 & 21 & 31 & 3.540 \\
\hline 10. Share files with colleagues & 14 & 14 & 25 & 17 & 17 & 3.103 \\
\hline $\begin{array}{l}\text { 11. Participate in the virtual classroom or chat } \\
\text { room }\end{array}$ & 28 & 13 & 16 & 13 & 17 & 2.747 \\
\hline
\end{tabular}

For items 1, 2, 3, 4, 5, 7, 8, 9 and 10, teachers have a frequency of use of electronic platforms that varies from "Often" to "Always". In items 6 and 11, the frequency of responses pointed to "Few Times". These items are largely related to the performance of teachers, who for the most part do not make the proper use of the concept of e-learning (ZUNGUZE and TSAMBE, 2020). Sending a set of PDFs on the Internet and answering students' questions by e-mail is not e-learning (MAGANO, CASTRO and VAZ de CARVALHO, 2008).

The last question was intended to know the level of difficulty encountered by teachers in each of the electronic platforms used for teaching of classes during the term of the 
State of Emergency due to Covid-19. The question had 9 items and the answers are shown in figure 8.

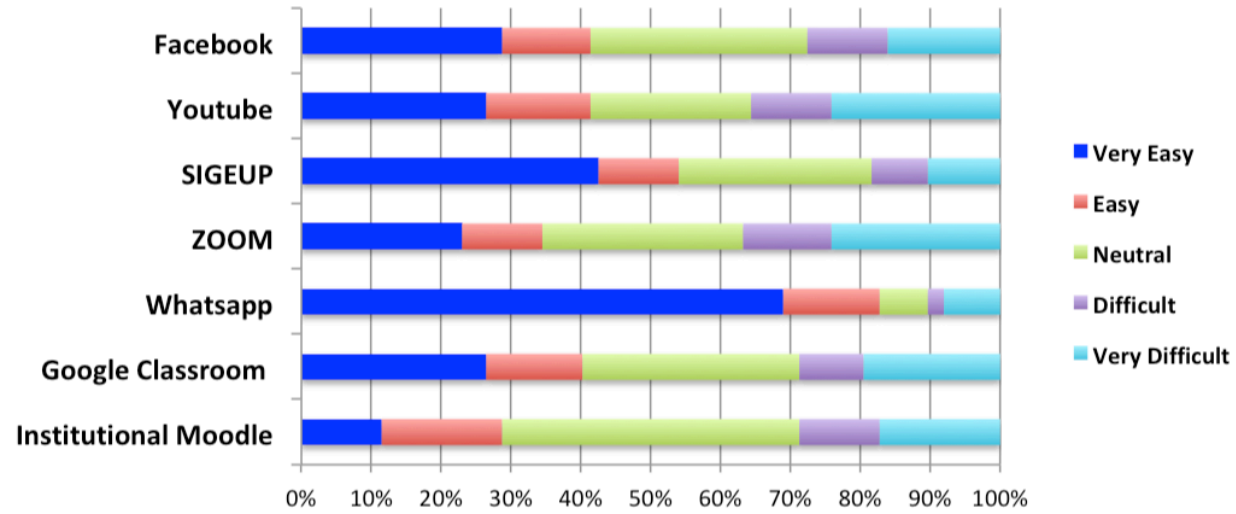

Figure 8. Level of difficulty encountered by teachers through electronic platforms.

The analysis of the average ranking in the items of the question was made for a better analysis of the results. They are shown in table 2 below.

Table 2: Average ranking of the items of frequency of difficult level encountered by teachers through electronic platforms

\begin{tabular}{lcccrrr}
\hline \multirow{2}{*}{ Item } & \multicolumn{6}{c}{ Frequency of responses for each item } \\
\cline { 2 - 8 } & $\mathbf{1}$ & $\mathbf{2}$ & $\mathbf{3}$ & $\mathbf{4}$ & $\mathbf{5}$ & \multicolumn{1}{c}{ AR } \\
\hline 1. Institutional Moodle & 10 & 15 & 37 & 10 & 15 & 3.057 \\
\hline 2. Google Classroom & 23 & 12 & 27 & 8 & 17 & 2.816 \\
\hline 3. Whatsapp & 60 & 12 & 6 & 2 & 7 & 1.666 \\
\hline 4. ZOOM & 20 & 10 & 25 & 11 & 21 & 3.034 \\
\hline 5. SIGEUP & 37 & 10 & 24 & 7 & 9 & 2.321 \\
\hline 6. Youtube & 23 & 13 & 20 & 10 & 21 & 2.919 \\
\hline 7. Facebook & 25 & 11 & 27 & 10 & 14 & 2.735 \\
\hline
\end{tabular}

In item 3, the teachers said that WhatsApp is very easy to use to conduct classes. For items 2, 5, 6 and 7 they said it is easy. This result is reinforced by the result shown in figure 4 , where about $82.8 \%$ of the teachers answered that they prefer to use mobile phones to teach their classes. Regarding items 1 and 4, the teachers were neutral as to the degree of difficulty that these platforms present. This is an indicator that shows that when it comes to virtual learning environments or platforms that need a greater bandwidth to be accessed, teachers tend to discard them.

\section{Conclusions}

This research aimed to analyze the perception of UP-Maputo teachers in the use of electronic platforms as a resource to support classroom teaching during the term of the State of Emergency due to the COVID-19 pandemic.

The research concluded that teachers are using different electronic platforms for the teaching process in the current scenario. The main platforms that are being used in this COVID-19 period are email, WhatsApp, SIGIUP and Moodle. The use of these platforms by teachers had its greatest impact in this period, in the perspective of increasing users in the scenario of the appearance of COVID-19. This increase is a consequence of the absence of teacher-student interaction and vice versa in the traditional sense of teaching. Regarding to the equipment that are used by teachers to 
access these platforms, it is worth mentioning the cell phone that is widely used in the teaching process after the laptop.

The Educational resources used by teachers on electronic as a teaching-learning activities was majority the text reading and self-video lessons. These teaching-learning activities were evaluated by differences instruments as identified as evaluated activities such as report of the student's activities, level of student participation, portfolio that should be delivery at the end of the emergency state, online tests and other.

The teachers assumes that they use, with considerable frequency, the electronic platforms basic to participate in the virtual classroom, provide the study plans, provide materials from the disciplines, send assignments, email students, answer student's questions, share files and participate in the discussions forum. The study also concluded that most teacher consider the YouTube, Zoom and Google Classroom as the platforms that their encounter a lot of difficult to manage it when compared by others such as WhatsApp, Facebook and other institutional platforms that were used in the normal state to provide de e-learning.

\section{References}

Ceccim, R. B. Feuerwerker, L. M. (2004). Mudança na Graduação das Profissões de Saúde sob o eixo da integralidade. Cadernos de Saúde Pública, Rio de Janeiro, v. 20, n. 5, p. 14001410 .

Delgado, L.M.M. \& Haguenauer, C.J. (2010). Uso da Plataforma Moodle no Apoio ao Ensino Presencial: um Estudo de Caso. Revista EducaOnline. ISSN 1983 2664. V.4 nr. 1, p. 1126.

Freire, P. (1996). Pedagogia da autonomia: saberes necessários à prática educativa. 25. ed. São Paulo: Paz e Terra.

Gomes, M. J. (2008). Na senda da Inovação tecnológica da Educação da Distância. Revista Portuguesa de Pedagogia.

Magano, J., Castro, A. V., \& Vaz de Carvalho, C. (2008). O e-Learning no Ensino Superior: um caso de estudo. In Educação, Formação \& Tecnologias, n.1 (vol. 1), 79-92. [Online]; available from http://eft.educom.pt (accessed October 12, 2020).

Palácio, M. A. V. \& Struchiner, M. (2016). Análise do uso de recursos de interacção, colaboração e autoria em um ambiente virtual de aprendizagem para o ensino superior na área da saúde. Ciênc. Educ., Bauru, v. 22, n. 2, p. 413430.

Plano Estratégico de Educação à Distância (PEED) (2013). Estratégia de Educação a distância 2014 2018. Governo de Moçambique. Maputo.

Samartinho, A. C. O. G. F. (2010) As tecnologias da informação e da comunicação como facilitadoras da aprendizagem no 1o CEB: Estudo de caso utilizando a plataforma Moodle na aprendizagem matemática (Dissertação de mestrado, Instituto Politécnico de Santarém).

Zunguze, M. C \& Tsambe, M. Z. A. (2020). Switching from face to face to electronic mediated education caused by COVID 19 pandemic: An analysis of student perceptions. International Journal for Innovation Education and Research, ISSN: 2411-2933. Vol. 8 nr. 07, Page.249 262. 